\title{
KEYNESIN TOINEN TULEMINEN?
}

Elinkeinoministeri Jan Vapaavuori julisti vuoden 2014 alussa järjestämänsä Selkärankaseminaarin innostamana, että "yksityinen sektori maksaa julkisen sektorin palkat". Ministerin mukaan suomalainen hyvinvointi syntyy nimenomaan yritysten menestyksestä. Yksi Vapaavuoren lausuman oletus on, että julkisen sektorin työntekijät ovat loisia, jotka syövät yritysten elinvoimaa. OECD:n tuoreen ennusteen mukaan Suomen julkinen sektori on maailman suurin vuonna 2014, 58 \% BKT:sta.

Hallituksen talouspoliittiset linjaukset ovat olleet tämän oletuksen ja vallitsevan uusklassisen taloustieteen mukaisia: julkista sektoria on pyritty supistamaan voimakkaasti, koska nimenomaan sen on väitetty olevan este talouskasvulle. Koko julkinen sektori on ikään kuin yksi valtaisa tulonsiirto yrityksiltä valtiolle, kunnille ja muille julkisyhteisöille. Yksityinen sektori tuottaa lisäarvoa ja varallisuutta, jonka julkinen tuhlaa.

Esimerkiksi Taloussanomat (16.1.2014) kuitenkin kyseenalaisti talousseminaareissa voivotellun luvun julkisten menojen suhteesta BKT:hen, koska Suomen luku ei ole suoraan vertailukelpoinen muihin maihin. Luku nousee Suomessa 13 prosenttiyksikköä jo siksi, että julkisen sektorin menoihin kirjataan niin julkisella kuin yksityiselläkin sektorilla tehdystä työstä maksetut eläkkeet. Lisäksi luku on helppo ymmärtää värin. Kyse on kahden tunnusluvun suhteesta, ei kuva julkisen sektorin menojen osuudesta bruttokansantuotteesta. Julkisten ja yksityisten menojen summa ei ole sata, koska julkisten ja yksityisten menojen sijaan bruttokansantuote muodostuu arvonlisäyksestä.

Faktojen valinta onkin olennainen osa talouspolitiikkaa. Esimerkiksi Helsingin Sanomien kokoaman HS-raadin enemmistön mielestä Suomessa takerrutaan talouspolitiikassa yhteen vaihtoehtoon (HS 18.2.2014). Eikö olisi siis aika keskustella talouden periaatteista monipuolisemmin? Vastuu yksioikoistuvista ja vain yhtä poliittista linjaa edustavista "itsestän̈nselvyyksistä" talouskeskustelussa ei ole ainoastaan valtavirtaisten taloustieteilijöiden, virkamiesten ja poliitikkojen harteilla. Myös yhteiskuntatieteilijöiden on suhtauduttava vakavammin taloudellisiin ongelmiin ja pyrittävä ymmärtämään tarkemmin monimutkaisia talouden, politiikan, kulttuurin ja yhteiskunnallisen toiminnan yhteenkietoutumia. Talous on aivan liian tärkeä asia jätettäväksi vain "talouden ammattilaisten" huoleksi.

Hegemoninen talousdiskurssi ja sen totuudet tunkeutuvat jatkuvasti syvemmälle sekä yhteiskunnan eri alueille että ihmisten välisten suhteiden järjestämiseen. Talouspuheen tuottama "totuusregiimi" suorastaan vaatii kriittistä katsetta. Poliitikkojen puheita kuunnellessa ei voi olla enää varma, puhuvatko he nimenomaan näiden itsestäänselvyyksien ja oletusten varassa vai onko heidän puheidensa taustalla syvempää ymmärrystä talouden toiminnasta. Moni kovaääninen talouskeskustelija on viime vuosina verrannut esimerkiksi valtion taloutta kotitalouteen, vaikka ne noudattavat eri lainalaisuuksia. Vallitseva "arkijärki" näyttää kuitenkin usein heijastelevan uusklassista paradigmaa, ja siksi keskusteluun on tarjottava vaihtoehtoisia analyyseja tosiasioista.

Niin John Maynard Keynes (1883-1946) kuin hänen kirjoitustensa pohjalta syntyneiden makrotaloustieteellisten suuntausten edustajat haastavat Vapaavuorenkin edustaman uusklassisen käsityksen taloudesta ja sitä ylläpitävistä totuuksista. Uusklassinen talousparadigma valtasi länsimaisen taloustieteellisen ajattelun niin sanotun Bretton Woodsin (1944-1971) järjestelmän kaatumisen jälkeen. Bretton Woods perustui osittain Keynesin suunnitelmaan globaalisti säädellyistä finanssimarkkinoista, ja siihen liittyi monien länsimaiden aktiivinen pyrkimys täystyöllisyyspolitiikkaan. Dollarin irrottaminen kultakannasta kaatoi järjestelmän. Tämän jälkeen länsimaisessa makrotaloudessa tukeuduttiin pääasiassa Chicagon yliopistossa kehitettyyn ns. monetaristiseen teoriaan, jonka yksi pääarkkitehti oli uusliberalismin guruna tunnetuksi tullut Milton Friedman (1912-2006). 
Keynesiläisyys ei kuitenkaan täysin kadonnut valtavirran taloustieteestä, vaikkei sitä koskaan harjoitettukaan "puhtaassa" muodossa. Keynesiläisyys vaikutti vielä 1980-luvulla käytännössä monien maiden talouspolitiikassa, ja uudet tulkinnat Keynesin teoriasta, kuten vaikkapa yhdysvaltalaisen talousnobelisti Joseph Stiglitzin (s. 1946) oletusta markkinoiden automaattisesta tehokkuudesta kritisoinut uuskeynesiläisyys, vaikuttivat monin tavoin keskusteluihin taloustieteessä. Viimeistään 1990-luvun laman jälkeen uusklassinen taloustiede ja uusliberaali politiikka ovat kuitenkin omineet itselleen valtavirtaisen taloustieteen aseman niin käytännön talouspolitiikassa kuin taloustieteen oppituoleissakin.

Miksi siis palata Keynesiin? Toisen maailmansodan jälkeen harjoitettu keynesiläinen talouspolitiikka mahdollisti monia sellaisia yhteiskunnallisia edistysaskeleita, jotka nykyisen talousparadigman aikakaudella tuntuvat utopioilta. Täystyöllisyyden tavoittelu loi runsaasti työpaikkoja tietyistä markkinaheilahteluista huolimatta, ja esimerkiksi työttömyys- ja sosiaaliturvan kehittäminen vähensi köyhyyttä ja teki talouden laskukausista sosiaalisesti, poliittisesti ja taloudellisesti siedettävämpiä. Eurooppalaiset hyvinvointivaltiot ovat tämän prosessin seurausta, joskaan eivät tietenkään kokonaan keynesiläisen talouspolitiikan ansiota.

Uusklassisen paradigman seurauksena tuloerot ovat suorastaan räjähtäneet myös Suomessa 1990-luvun laman jälkeen. Toisaalta vuonna 2008 alkaneen finanssi- ja talouskriisin jälkeen myös monien valtavirtaisten talousteoreetikkojen on täytynyt todeta, että uusklassinen teoria on pahoissa ongelmissa. Yhdysvalloissa keskuspankki on päätynyt painamaan setelirahaa rahamarkkinoiden tarpeisiin ja maan hallitus on nostanut toistuvasti velkakattoa. Euroopassa keskuspankki on puolestaan sitonut kätensä vyönkiristysoppeihin, minkä seurauksena moni eurooppalainen hyvinvointivaltio on ryhtynyt supistamaan julkista sektoriaan lähes paniikinomaisissa tunnelmissa.

Vaikuttaakin siltä, että tiettyä epätietoisuuden ja pelon ilmapiiriä pidetään talouskeskustelussa aktiivisesti yllä. Jo siksi keskustelu keynesiläisen talouspolitiikan vaihtoehdoista on tärkeää. Kriittinen keskustelu suurista talouspoliittista linjoista lisää läpinäkyvyyttä ja paljastaa toimijoiden poliittisia agendoja. Asiallinen, kriittinen ja monipuolinen keskustelu myös lisää maltillisuutta, mikä on tärkeää suurista yhteiskunnallisista muutoksista päätettäessä. Talouspoliittiset linjaukset eivät ole pakon sanelemia, etenkään pitkällä aikavälillä. Talous kun ei koskaan ole irrallista politiikasta - nämä kaksi "sfäriä" ovat täysin yhteenkietoutuneita.

Otsikolla "Keynesin toinen tuleminen?" haluamme kiinnittää huomion jälkikeynesiläisen ajattelun voimistumiseen ja sen tarjoamiin uudenlaisiin talouspoliittisiin ratkaisumalleihin. Kysymme myös, voidaanko vuonna 2008 alkaneen talouskriisin jälkiselvittelyä nähdä keynesiläisen politiikan paluuna. Kolmanneksi haluamme otsikollamme myös ironisesti muistuttaa talouteen liittyvästä dogmaattisuudesta. Talous on nykyisin saanut lähes metafyysisen tai hallitsemattoman luonnonvoiman aseman, minkä vuoksi eräänlainen talouden sekularisointi on tarpeen. Talous on ihmisten luoma järjestelmä, ei omalakinen, kaikkeen vaikuttava ja kaiken selittävä puolimystinen ilmiö.

Ajatus teemanumerosta syntyi lukuvuonna 2012-2013 Jyväskylän yliopistossa järjestämästämme 1900-luvun talouden poliittisuutta koskevasta tutkimuskurssista, ja kirjoittajat valikoituivat huhtikuussa 2013 järjestetystä Keynesin ajattelua käsitelleestä kollokviosta.

Keynesin toinen tuleminen? -teemanumeron artikkelit esittelevät monipuolisesti ja kriittisesti jälkikeynesiläistä talousajattelua. Ne käsittelevät taloutta osana yhteiskuntaa ja korostavat siksi poliittisen päätöksenteon ja ohjauksen roolia. Toivomme, että artikkelit auttavat arvioimaan sekä talouden roolia yhteiskunnassa että talouteen liittyviä, helposti kyseenalaistamatta hyväksyttyjä "totuuksia" nykyistä kriittisemmin. 